14 - ORIGINAL ARTICLE EXPERIMENTAL ORTHOPAEDIC SURGERY

\title{
Filling of extraction sockets with autogenous bone in cats ${ }^{1}$
}

\author{
Preenchimento de alvéolos dentais de gatos com osso autógeno
}

\author{
Adelina Maria da Silva', Wilson Machado de Souza", Nair Trevizan Machado de Souza'II, Marion Burkhardt de Koivisto ${ }^{\mathrm{IV}}$, \\ Patrícia de Athayde Barnabév, Tatiane da Silva Polóvi
}

${ }^{\mathrm{I}} \mathrm{PhD}$, Assistant Professor, Department of Clinics, Surgery and Animal Reproduction, UNESP, Araçatuba-SP, Brazil. Responsible for conception, design, intellectual and scientific content of the study; acquisition and interpretation of data; surgical procedures and radiographic examinations; manuscript writing; statistical analysis.

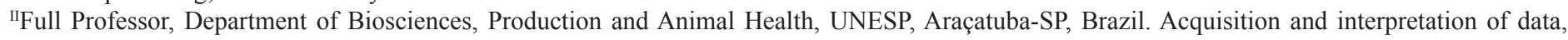
macroscopic and histopathological examinations, critical revision.

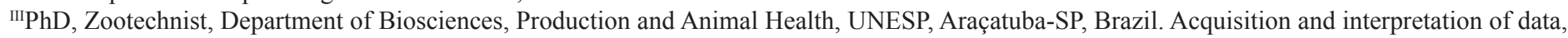
macroscopic and histopathological examinations.

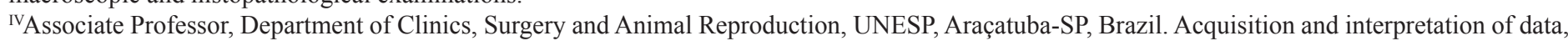
histometric examinations.

${ }^{\mathrm{v}} \mathrm{PhD}$, DVM, Department of Clinics, Surgery and Animal Reproduction, UNESP, Araçatuba-SP, Brazil. Acquisition and interpretation of data, histometric examinations.

${ }^{\mathrm{VI}}$ Graduate student, Department of Clinics, Surgery and Animal Reproduction, UNESP, Araçatuba-SP, Brazil. Acquisition and interpretation of data, surgical procedures and radiographic examinations.

\begin{abstract}
PURPOSE: To evaluate bone healing in the extraction socket of the feline mandibular canine tooth after grafting.

METHODS: Eighteen adult cats were submitted to unilateral extraction of mandibular canine tooth and divided into three groups. In group $1(n=6)$, control, the extraction socket was left empty. In group $2(n=6)$, the extraction socket was filled with autogenous cancelous bone from the iliac crest and in group $3(n=6)$, with cortical bone chips from the iliac crest. Cats were euthanized at 6 weeks postoperative.

RESULTS: Immediate postoperative radiographs in dorsoventral view showed a radiolucent area at the extraction wound. A decreased radiolucency was observed on the radiographs taken at 6 weeks postoperative. Histological examination showed formation of woven bone within the extraction socket. The percentage of newly formed bone within the extraction socket, measured by the histometry, showed no statistically significant difference among the values of the three groups (Kruskal-Wallis'test p $>0.05$ ) (group 1: $52.54 \pm 15.46$, group 2: $50.51 \pm 5.01$, group 3: $51.85 \pm 9.52$ ). CONCLUSION: The bone regeneration observed in the extraction sockets filled with autogenous cancellous bone or autogenous cortical bone chips was similar to that observed in the control sites, given an observation period of 6 weeks after extraction of the mandibular canine tooth.
\end{abstract}

Key words: Surgery, Oral. Bone Transplantation. Tooth Extraction. Tooth Socket. Cats.

\section{RESUMO}

OBJETIVO: Avaliar a regeneração óssea de alvéolos dentais de gatos após enxertia.

MÉTODOS: Dezoito gatos adultos, distribuídos em três grupos de 6 animais cada, foram submetidos a extração do canino mandibular direito ou esquerdo. No grupo 1, controle, o alvéolo foi deixado vazio. No grupo 2, o alvéolo foi preenchido com osso esponjoso autógeno do osso ilíaco e no grupo 3, com raspa de osso cortical do osso ilíaco. Os animais foram submetidos à eutanásia 6 semanas após a cirurgia.

RESULTADOS: Nas radiografias realizadas no pós-operatório imediato na projeção ventrodorsal observou-se uma área de radiolucência correspondente ao local da alveolectomia e extração dentária. Diminuição da radiolucência foi verificada nas radiografias realizadas seis semanas após a cirurgia. Nos cortes histológicos verificou-se a presença de trabéculas ósseas. A porcentagem de tecido ósseo esponjoso presente nos alvéolos dentais foi quantificada por exames histométricos. Não houve diferença estatisticamente significante entre os grupos (Teste de Kruskal-Wallis p > 0.05) (grupo 1: 52,54 \pm 15,4; grupo 2: 50,51 \pm 5,01; grupo 3: $51,85 \pm 9,52$ ).

CONCLUSÃO: Os alvéolos dentais de gatos preenchidos com osso esponjoso autógeno ou raspa de osso cortical autógeno apresentaram regeneração óssea similar àquela observada no grupo controle, após um período de observação de seis semanas.

Descritores: Cirurgia Bucal. Transplante Ósseo. Extração Dentária. Alvéolo Dental. Gatos. 


\section{Introduction}

The most common dental diseases in cats are: periodontal disease, feline odontoclastic resorptive lesions and feline chronic gingivostomatitis. These diseases often cause the loss of teeth or require dental extraction. Complicated crown fracture, with pulp exposure, is an injury that may also require ${ }^{1-5}$.

The filling of extraction sockets has been recommended to promote osseous growth and maintain alveolar ridge and jaw strength. A variety of bone graft materials have been tried, including autografts, allografts, synthetic materials, osteoinductive substances and osteogenic cells ${ }^{6-11}$.

Autogenous cancellous bone is regarded as the ideal graft as it provides scaffold for osteoconduction, growth factor for osteoinduction and progenitor cells for osteogenesis ${ }^{12,13}$. Cortical bone chips represent an alternative for autologous bone graft. Although they possess weak osteogenic potential, their osteoinductive property is intense $\mathrm{e}^{14,15}$.

The objective of the present study was to evaluate bone formation resulting from the placement of autogenous cancellous bone or autogenous cortical bone chips into fresh extraction sockets in cats.

\section{Methods}

This study was approved by the Ethics Committee for Animal Research of UNESP, Araçatuba-SP, Brazil.

\section{Animals and experimental design}

Eighteen healthy young adult (aging between 12 and 24 months) mixed breed cats (weighing $2.9 \pm 0.4 \mathrm{~kg}$ ) were utilized. Nine spayed females and 9 neutered males were used and evenly distributed among 3 groups. Unilateral extraction of mandibular canine tooth was performed at random in either the right or left side. In group 1, control, the extraction socket was left empty. In group 2, the extraction socket was filled with autogenous cancelous bone from the iliac crest and in group 3, with autogenous cortical bone chips from the iliac crest. Cats were euthanized at 6 weeks postoperative

\section{Surgical procedure}

Food was withheld for 12 hours prior to anesthesia. The cats were premedicated with atropine $(0.05 \mathrm{mg} / \mathrm{kg} \mathrm{SC})$, xylazine $(2 \mathrm{mg} / \mathrm{kg} \mathrm{SC})$ and ketamine (15 mg/kg SC). Thiopental $(5 \mathrm{mg} / \mathrm{kg}$
IV) was administered to allow endotracheal intubation. Inhalation anesthesia was maintained with halothane and oxygen. Fentanyl $(0.0125 \mathrm{mg} / \mathrm{kg} \mathrm{IM})$ was administered after anesthesia induction. Lactated Ringer's solution (10 mL/kg IV) was administered throughout anesthesia. Ketoprofen $(2 \mathrm{mg} / \mathrm{kg}, \mathrm{SC})$ and enrofloxacin $(5 \mathrm{mg} / \mathrm{kg}, \mathrm{SC})$ were administered preoperatively and for 3 days postoperatively.

Cats of group 2 and 3 were positioned in lateral recumbency and the iliac crest region was clipped, prepared, and draped under sterile technique. Using a $\mathrm{n}^{\circ} 10$ Bard-Parker blade, a $4 \mathrm{~cm}$ incision was made over the iliac crest. The subcutaneous tissue, gluteal fat and thoracolumbar fascia were incised to expose the crest and the wing of the ilium. In group 2, a block of cortico-cancellous graft was harvested from the iliac wing with an osteotome and mallet. Small particles of cancellous bone (1 to $3 \mathrm{~mm}$ diameter) were obtained and stored in saline at room temperature. In group 3, cortical bone chips were harvested from the lateral side of the iliac wing with a bone scraper for multiple use with replaceable blade. The cortical bone chips were also stored in saline at room temperature. Subcutaneous layer was closed with 3-0 polyglicolic acid. Skin closure was with 4-0 nylon. Skin sutures were removed after 7 days.

Thereafter the cats of the 3 groups were prepared for oral surgery with povidone-iodine. Local anesthesia of the inferior alveolar nerve was done with mepivacain $(7 \mathrm{mg} / \mathrm{kg})$ and epinephrine. A buccal mucoperiosteal flap was raised with periosteal elevator to expose the extraction socket of the mandibular canine tooth. A burr on a slow-speed handpiece under irrigation with sterile saline was used to perform buccal alveolectomy. Periodontal elevator and extraction forceps were used to complete the extraction. On completed extraction, the remaining alveolus was debrided with a curet and irrigated with sterile saline solution. In group 1, control, the extraction socket was left empty. In group 2, the extraction socket was filled with autogenous cancelous bone from the ilium and in group 3, with autogenous cortical bone chips from the ilium. The flap was sutured with 4-0 polyglactin 910 in a simple, interrupted pattern.

\section{Postoperative observations and radiographs}

Oral alimentation was reinitiated 24 hours after surgery with canned food. This soft food was offered during 5 days. After this period, the animals were fed with commercial dry feline diet. Radiographs were performed immediately after surgery and at the end of the study, i.e., after 6 weeks postoperative. The lateral and dorsoventral views of the mandible were taken. 


\section{Macroscopic analysis, histolopathology and histometry}

The cats were euthanized at 6 weeks postoperative by intravenous thiopental overdosage. Block sections of the mandible that contained the extraction wounds were prepared, fixed in $10 \%$ formalin and decalcified in an aqueous solution of 5.66 formalin $10 \%$ to 1 of nitric acid $(\mathrm{v} / \mathrm{v})$. The demineralised specimens were dehydrated in ethanol, clarified in xylol and embedded in paraffin. Thin sections were made transversely and stained with hematoxylin-eosin for microscopic evaluation. For the histometric analysis, the images of sections were acquires using a digital camera (Olympus DP71) coupled to a microscope (Olympus BX61). The percentage of newly formed bone within the extraction socket was measured using the Image Pro Plus 6.1 software.

\section{Statistical analysis}

Non-parametric tests were utilized for the data analysis, taking into consideration the nature of the variables. KruskalWallis' test was used to compare histometric data among the three groups. Significance was set at $\mathrm{p} \leq 0.05$.

\section{Results}

There were no clinical complications and the extraction wounds healed uneventfully. The synthetic absorbable sutures applied to the gingiva disappeared in 15 days after surgery. During the experimental period the cats showed normal activity and mastication.

Crown and/or root fracture occurred in 10 of 18 extractions and the histological sections of 2 cats of group 1, one from group 2 and one from group 3 showed root remnants. Even so, there was no case of inflammation or fistulation in the extraction wounds.

Cats from groups 2 and 3, in which autogenous bone graft was harvested from the iliac wing, showed normal deambulation after surgery. The surgical wounds in the iliac crest region also healed satisfactorily.

Immediate postoperative radiographs in dorsoventral view showed a radiolucent area at the extraction wound (Figure 1). A decreased radiolucency was observed on the radiographs taken at 6 weeks postoperative (Figure 2). No features were observed on the radiographs taken in lateral projection in the immediate postoperative period and 6 weeks after surgery, due to overlap of the canine tooth in the contralateral side of the jaw.

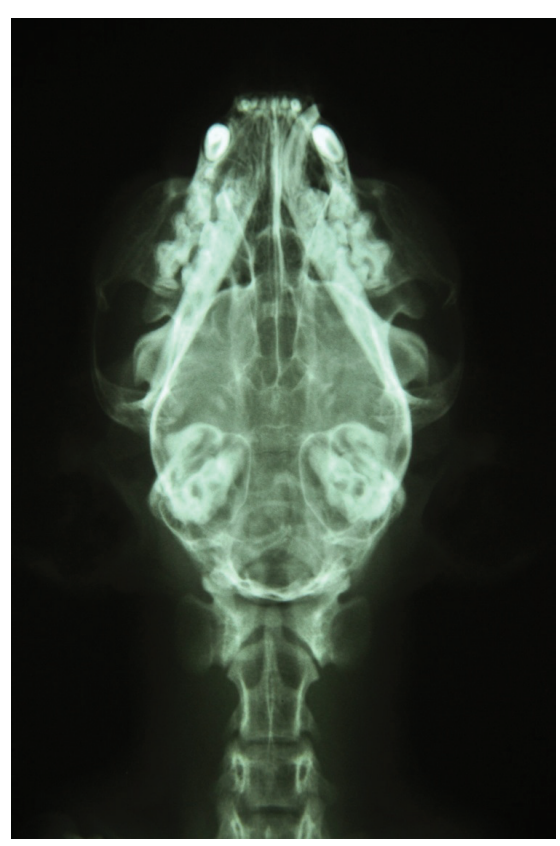

FIGURE 1 - Radiograph in dorsoventral projection taken immediately postoperative shows a radiolucent area at the extraction wound. Cat 18 of Group 3.

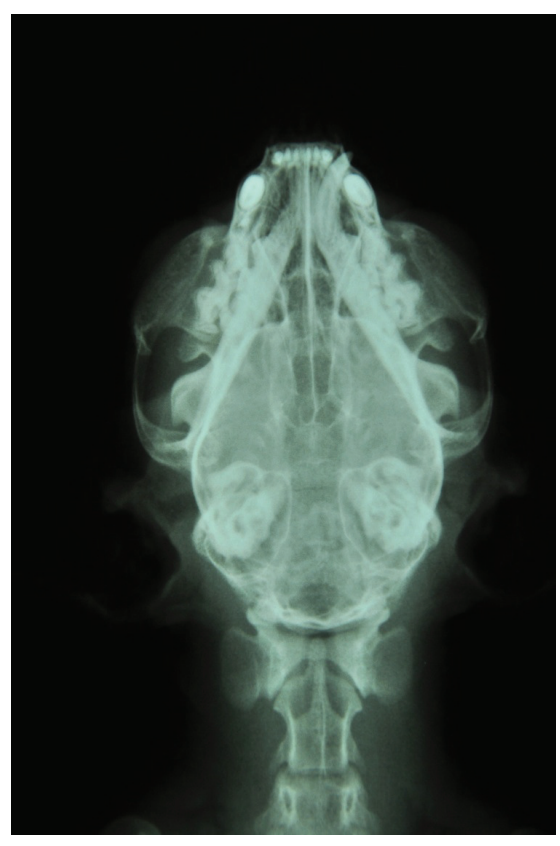

FIGURE 2 - Radiograph in dorsoventral projection taken 6 weeks after surgery shows the decreased radiolucency at the extraction wound. Cat 18 of Group 3.

\section{Histological examination showed formation of} woven bone within the extraction socket (Figures 3, 4 and 5). Areas of connective tissue were seen among bone trabeculae, indicating that the regeneration of extraction socket occurred by intramembranous ossification. The percentage of newly formed bone within the extraction socket was measured by the histometry. 
There was no statistically significant differences among the values of the three groups (Kruskal-Wallis'test $\mathrm{p}>0.05$; group 1: $52.54 \pm$ 15.46, group 2: $50.51 \pm 5.01$, group 3: $51.85 \pm 9.52$; Table 1)

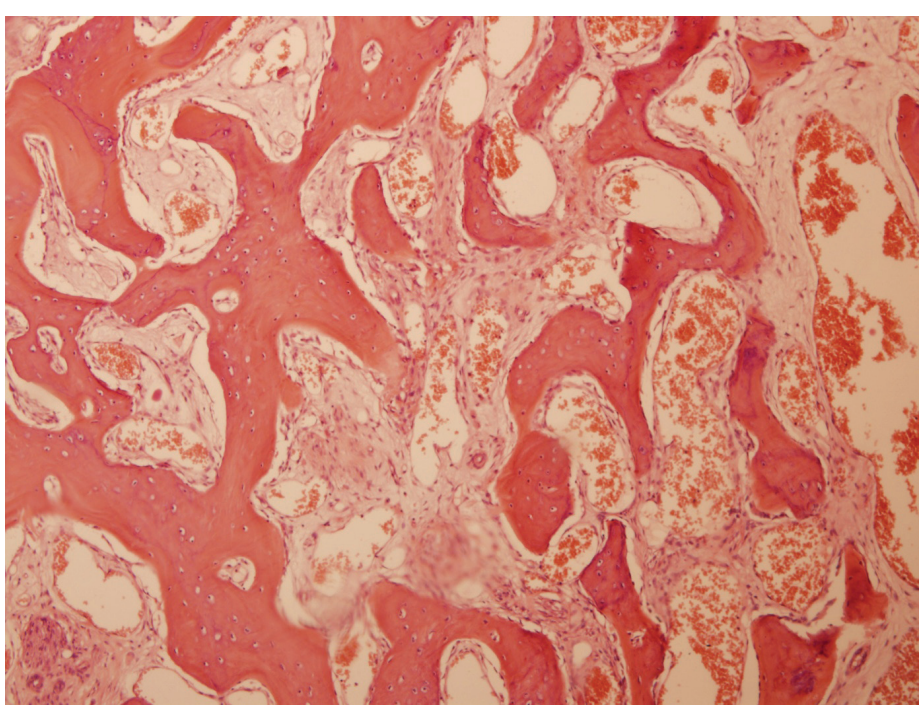

FIGURE 3 - Histologic section of extraction socket after 6 weeks shows woven bone formation. Cat 3 of Group 1 (control) specimen. (HE - 100X).

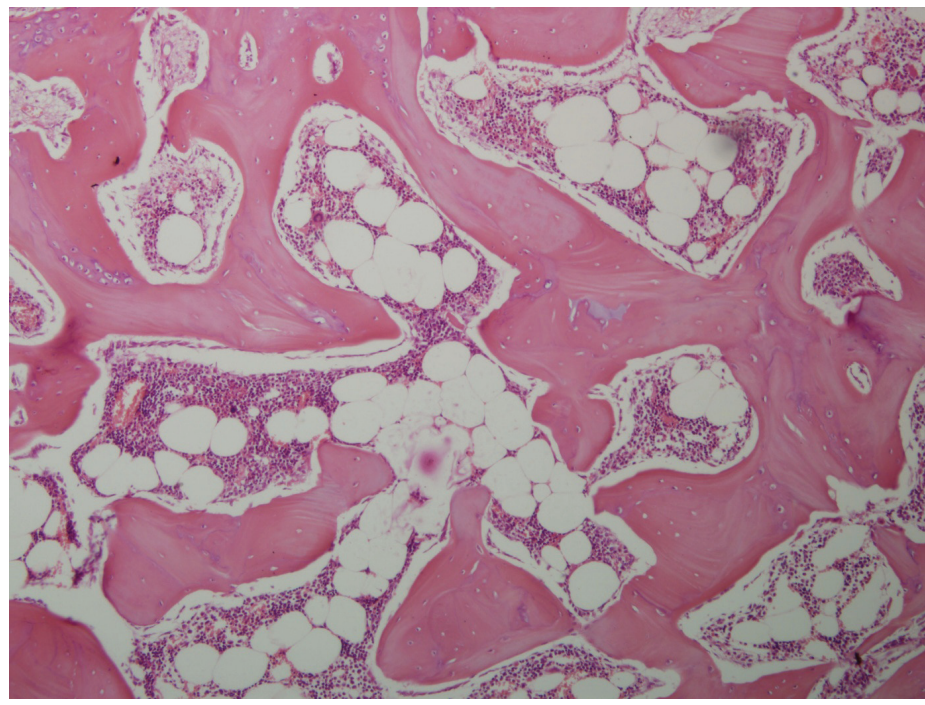

FIGURE 4 - Histologic section of extraction socket after 6 weeks shows woven bone formation. Cat 11 of Group 2 (cancelous bone particles) specimen. (HE - 100X).

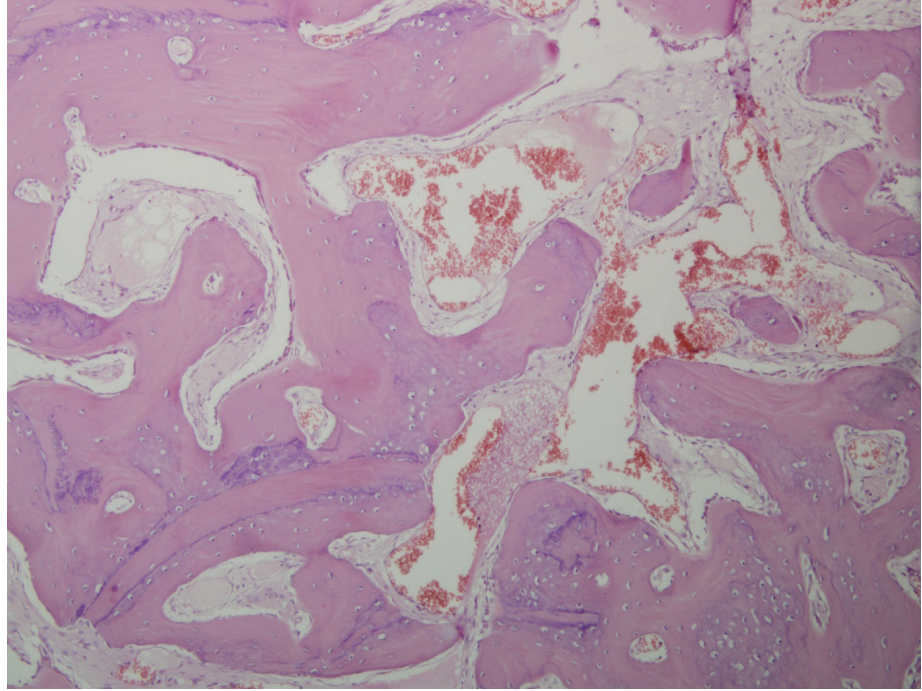

FIGURE 5 - Histologic section of extraction socket after 6 weeks shows woven bone formation. Cat 16 of Group 3 ( cortical bone chips) specimen. (HE - 100X).

TABLE 1 - Bone fill percentage within the extraction socket 6 weeks after extraction of mandibular canine tooth.

\begin{tabular}{cccc}
\hline Statistic & $\begin{array}{c}\text { group 1 } \\
\text { control }\end{array}$ & $\begin{array}{c}\text { group 2 } \\
\text { cancelous } \\
\text { bone graft }\end{array}$ & $\begin{array}{c}\text { group 3 } \\
\text { cortical } \\
\text { bone chips }\end{array}$ \\
\hline 77.85 & 56.51 & 66.88 \\
& 59.57 & 53.30 & 56.93 \\
& 55.28 & 52.07 & 54.14 \\
& 47.93 & 50.16 & 46.65 \\
& 39.61 & 49.35 & 46.47 \\
Mean & 34.98 & 41.69 & 40.00 \\
\hline Standard deviation & 15.46 & 5.01 & 9.52 \\
Median & 51.61 & 51.12 & 50.40 \\
\hline
\end{tabular}

Kruskal-Wallis' test $\quad \mathrm{H}=0.011898 \mathrm{P}>0.05$

\section{Discussion}

The local anesthesia of the mandibular inferior alveolar nerve reduced inhalant anesthetic requirement and decreased pain after surgery. Other measures recommended to control postoperative pain of teeth extractions, as the use of non-steroidal anti-inflammatory drugs and soft food, were adopted in the present 
study $y^{5,8}$.

Even after extensive exposure of the root, the canine tooth remains firmly adhered to the mandible and considerable force is necessary to disrupt the periodontal ligament. In cats and small dogs, the jaw can be fractured by excessive force. Therefore, the surgeon must keep the largest possible contact between their fingers and the mandible, to dissipate the applied forces. In the present study, no case of mandible fracture occurred. However, the fracture of the crown and/or the root was observed in 10 out 18 cats undergoing dental extraction, confirming that the thin and delicate teeth of cats are particularly susceptible to fractures. The fragments were retrieved, but the histological examination showed microscopic root remnants in 4 cats. These animals did not present inflammation or fistulation in the extraction wounds.

In order to facilitate surgical procedures, harvesting of autogenous bone was performed before tooth extraction in the present study. According to Laursen et al. ${ }^{16}$, that investigated the quality of autogenous bone graft by means of osteoblast-like cell proliferation in vitro, there was no statistically significant difference between the samples harvested shortly before the grafting procedure and those storaged in saline solution at room temperature for up to 2 hours.

In group 2 of this study, the extraction sockets were filled with particulate cancellous bone. We used small particles of 1 to $3 \mathrm{~mm}$ diameter. In an experiment with rabbits, Pallesen et al. ${ }^{17}$ found better bone regeneration in defects filled with small autogenous bone particles $\left(0.5\right.$ to $\left.2 \mathrm{~mm}^{3}\right)$ than in those filled with large particles of $10 \mathrm{~mm}^{3}$.

Bone loss resulting from partial alveolectomy and absence of canine tooth was not observed on radiographs in lateral projection taken in the immediate postoperative period due to the overlapping of the bones. Nevertheless an area of radiolucency was detected at the extraction wound on the radiographs in dorsoventral view. Decreased radiolucency was observed on radiographs taken 6 weeks after surgery.

Six weeks after extraction of the mandibular canine, the extraction socket was filled with trabeculae of cancellous bone. The result of histological examination of this study is in agreement with those obtained in experiments in which the observation period was extended by several weeks ${ }^{7-10,15}$.

Indovina $\mathrm{Jr}$ and $\mathrm{Block}^{8}$ evaluated the healing response with different bone substitute materials in extraction sockets in dogs. Histological examination made after an observation period of 8 weeks showed that the sockets left empty contained woven bone. The particulate anorganic bovine bone sites were similar to the control sites. The calcium phosphate sites were filled predominantly with the graft material without evidence of resorption and replacement of the materials, and with minimal bone formation.

The histometric data of the present study showed that there was no statistically significant difference among groups, i.e., the percentage of trabecular bone tissue in extraction sockets filled with cancellous bone $(50.51 \pm 5.01)$ or cortical bone chips $(51.85$ $\pm 9.52)$ was similar to that observed in sockets left empty (52.54 $\pm 15.46), 6$ weeks after extraction of the mandibular canine tooth.

The experimental study in dogs of Araújo and Lindhe ${ }^{15}$ showed that the anorganic bovine sites exhibited a delayed healing pattern in comparison with sockets that had been filled with chips of autologous bone harvested from the mandible. The histometric examinations performed after 3 months of healing showed less mineralised bone in the xenograft-treated sites (43.5 versus $57.2 \%)$.

Histometric examinations of the experimental study in dogs of Gauthier et al. 7 demonstrated that the mean rate of newly formed bone in extraction sockets filled with calcium phosphate (45\%) was lower to that observed in control sites (64\%), 3 months after tooth extraction. Another histometric study in dogs suggested more intensive bone regeneration in the early healing phase $(6$ weeks) when platelet-rich plasma was combined with tricalcium phosphate for the filling of extraction sockets, since the percentage of bone area was lower in the control group than in the test group $(30.8 \pm 18.8 \% \text { versus } 45.9 \pm 20.6 \%)^{9}$. In a canine study, the measured bone formation after 49 days was $34 \%$ in the extraction sockets filled with hydroxyapatite/tricalcium phosphate cylinders loaded with mesenchymal stem cells ${ }^{10}$.

\section{Conclusion}

The bone regeneration observed in the extraction sockets filled with autogenous cancellous bone or autogenous cortical bone chips was similar to that observed in the control sites, given an observation period of 6 weeks after extraction of the mandibular canine tooth.

\section{References}

1. Harvey C. Management of periodontal disease: understanding the options. Vet Clin North Am Small Anim Pract. 2005;35:819-36.

2. Reiter AM, Mendoza KA. Feline odontoclastic resorptive lesions an unsolved enigma in veterinary dentistry. Vet Clin North Am Small Anim Pract. 2002;32:791-837.

3. Lyon KF. Gingivostomatitis. Vet Clin North Am Small Anim Pract. 2005;35:891-911.

4. Niemiec BA. Fundamentals of endodontics. Vet Clin North Am 
Small Anim Pract. 2005;35:837-68.

5. Niemiec BA. Extraction techniques. Top Companion Anim Med. 2008;23:97-105.

6. DeForge DH. Evaluation of Bioglass/PerioGlas (Consil) synthetic bone graft particulate in the dog and cat. J Vet Dent. 1997;14:141-5.

7. Gauthier O, Boix D, Grimandi G, Aguado E, Bouler JM, Weiss P, Dacul G. A new injectable calcium phosphate biomaterial for immediate bone filling of extraction socket: a preliminary study in dogs. J Periodont. 1999;70:375-83.

8. Indovina Jr A; Block MS. Comparison of 3 bone subsitutes in canine extraction sites. J Oral Maxillofac Surg. 2002;60:53-8.

9. Suba Z, Takacs D, Gyulai-Gaal S, Kovacs K. Facilitation of betatricalcium phosphate-induced alveolar bone regeneration by plateletrich plasma in beagle dogs: a histologic and histomorphometric study. Int J Oral Maxillofac Implants. 2004;19:832-8.

10. De Kok IJ, Drapeau SJ, Young R, Cooper, LF. Evaluation of mesenchymal stem cells following implantation in alveolar sockets: a canine safety study. Int J Oral Maxillofac Implants. 2005;20:5118 .

11. Abushahba F, Reventr S, Polyzois I, Claffey N. Effect of grafting materials on osseointegration of dental implants surrounded by circumferential bone defects. An experimental study in the dog. Clin Oral Implants Res. 2008;19:329-34.

12. Betz, RR. Limitations of autograft and allograft: new synthetic solutions. Orthopedics. 2002;25:561-70.

13. Vaccaro, AR. The role of the osteoconductive scaffold in synthetic bone graft. Orthopedics. 2002;25:571-8.

14. Slotte C, Lundgren D, Burgos PM. Placement of autogeneic bone chips or bovine mineral in guided bone augmentation: a rabbit skull study. Int J Oral Maxillofac Implants. 2003;18: 795-806.

15. Araújo MG; Lindhe J. Socket grafting with the use of autologous bone: an experimental study in the dog. Clin Oral Implants Res. 2011;22:9-13.

16. Laursen M, Christensen FB, Bünger C, Lind M. Optimal handling of fresh cancellous bone graft. Acta Orthop Scand. 2003;74:490-6.
17. Pallesen L, Schou S, Aaboe M, Hjørting-Hansen E, Nattestad A, Melsen F. Influence of particle size of autogenous bone grafts on the early stages of bone regeneration: a histologic and stereologic study in rabbit calvarium. Int J Oral Maxillofac Implants. 2002;17:498506.

\section{Correspondence:}

Adelina Maria da Silva

Univ. Estadual Paulista-UNESP

Depto. Clínica Cirúrgica e Reprodução Animal

Rua Clóvis Pestana, 793

16050-680 Araçatuba - SP Brasil

Tel.: (55 18)3636-1404

adelinasilva@fmva.unesp.br

adelinasilva@uol.com.br

Received: August 18, 2011

Review: October 19, 2011

Accepted: November 21, 2011

Conflict of interest: none

Financial source: FUNDUNESP

${ }^{1}$ Research performed at Department of Clinics, Surgery and Animal Reproduction, Division of Veterinary Surgical Technique, Sao Paulo State University (UNESP), Araçatuba-SP, Brazil. 